\title{
Drought-breaking love: An analysis of the moral values implied in "Drought"' by Jan Rabie $^{2}$
}

\author{
C.N. van der Merwe \\ Department of Afrikaans \& Netherlandic Studies \\ University of Cape Town \\ CAPE TOWN
}

\begin{abstract}
Drought-breaking love: An analysis of the moral values implied in "Drought" by Jan Rabie

In this article the tension in 20th century literary theory between absolutism and relativism is discussed. It is argued that, in spite of a movement from absolutism towards relativism, the age-old "absolute" values of truth, beauty and goodness have never been totally forsaken in the creation and the contemplation of literature. In an analysis of "Drought" by Jan Rabie, it is indicated how these values are implied and invoked in Rabie's short story In conclusion, the fundamental value of love or charity is discussed, a value which contains and supersedes the values of truth, beauty and goodness, and reconciles the tension between absolutism and relativism.
\end{abstract}

\section{What is literature?}

What is literature? And: What is the value of literature? These are questions that keep nagging at the minds of the students of literature. Questions like these are always cropping up, because they can never be completely answered. In the following article I would like to present another incomplete and unsatisfactory answer to these questions about the nature and value of literature.

Looking at the theory of literature in the 20th century, it becomes clear that many different answers about the nature of literature have been given, and each view has different implications about the use and value of literature. Literature has, inter alia, been regarded as:

1 Sec appendix at the end of article

2 Reworked version of a paper originally presented at the International Conference on "Christianity and literature at the turn of the century". Potchefstroom, August 1995. 
* An (aesthetic) structure.

* A means of expression.

* A means of persuasion.

* A vehicle for mimesis.

* A way of communication - communicating a "message" from an author to a reader in a text about (i.e.) society.

So we see that many different answers have been given to questions about the nature and value of literature, each answer apparently containing some truth. No simple and all-embracing answer can be given to these fundamental questions.

\section{From absolutist to relativist}

In the course of this century, literary theory has developed from an absolutist to a more relativist view of literature. This development was linked to changes in views on the literary text - the text, initially regarded as an autonomous whole, was eventually seen as one of a number of interdependent links in a communication process involving the author, the reader and society. Two different attitudes: the one seeing the literary text as an absolute and autonomous whole; the other as a dependent link in a communication chain.

What is meant by the concepts "absolute" and "absolutist", "relative" and "relativist"? With "absolute" I mean "constant", "unchanging"; as it is formulated in Collins' Concise English Dictionary (1978): "Existing in and by itself, without relation to anything else". An absolute value is a value which is valid at all times and under all circumstances.

"Relative", on the other hand, implies that something is inconstant and variable; determined (partly) by its context and the relations in which it is involved. A relative value cannot be valid at all times; it is partly determined by circumstances.

Within an absolutist framework, absolute values are presupposed and pursued. The formalist approach of the "New Critics", who played a leading role in the theory of literature for two or three decades after the Second World War, is a good example of absolutist criticism. The text was detached by these critics from its relations, its links with the author, the reader and society. Its structure was seen as fixed and constant. Formalists strived to keep subjective elements out of the interpretation and evaluation of the text; "correct" analyses had to be "proved" with reference to the text. The meaning of the text was seen as something existing inside the text, to be discovered by a competent reader, and 
the aesthetic element resided in the structure of the text, to be uncovered by the literary student. "New Critics" looked for the unchanging and universal; they were not interested in accidental variables like an author, a reader and a particular society.

In contrast, later theorists were more relativistic. Roland Barthes and Stanley Fish, for instance, stressed the role of the subjective reader; the latter believes the aesthetic value of literature not to reside in the text, but to be a projection of the reader onto the text, and the reader to be a producer rather than a discoverer of meaning.

Similarly, ideology criticism often focused on subjective elements in literary communication. The writer, rather than expressing universal ideas, is seen to be determined by a specific ideology dominant in a specific society, and the text forms part of a struggle for power in that society.

From absolutist to relativist - that is one of the major developments in literary criticism during the past century: a development from a belief in constant and universal values embodied in the text, to an emphatic belief in the uniqueness not only of every text, but also of every encounter between reader and text.

In this development, literary theory was not alone; it followed in the wake of developments in philosophy and the arts during the past century - from the security of realism through the uncertainty of modernism to the lability of postmodernism.

\section{Transcendental values}

Yet, in the search of literary theorists for the essence of literature, age-old absolute values have never been totally forsaken. I am thinking here of transcendental values, formulated, reformulated and adapted by Plato, Aristotle, Plotinus, Augustine, Aquinas and others; specifically the transcendental values of beauty, truth and goodness (comp. Rahner, 1970:285-287; Phillips, 1957:174179). I want to examine briefly how the different views on the nature and value of literature, mentioned at the outset, often imply the values of beauty, truth and goodness. Although I shall distinguish between these three concepts, they can never be totally separated from one another. Plato was right when he "believed that the supreme values - the good, the beautiful and the true - were ultimately one" (Preminger, 1990:618).

\subsection{Truth}

There are many definitions of truth; I am using the correspondence theory of truth 
in this article. This view on truth is succinctly formulated by Peter Caws (1966:15):

The most straightforward way of defending the truth of a statement about the world of experience is to point to the state of affairs it describes; if the state of affairs corresponds to what has been asserted, everybody will agree that the statement is a true one.

There are many problems about this approach - the most obvious one is that we cannot find a point of total objectivity from where we can determine the objective truth. Every statement, but also every point of observation, is determined by the subjectivity of the speaker, the listener and the observer. So who will be the judge to determine what is true?

And yet, implicit in all communication, traces of the correspondence theory of truth remain; if we had to put a total ban on the concept of truth, on the idea that language refers to something, it would mean the collapse of all communication. The idea that literature is a form of communication, one of the five views on literature referred to earlier, implies that there is "something" being communicated, something "behind" the words - one cannot just communicate, without communicating something. That "something" to which the words correspond, that is linked to the concept of truth. Whatever literature communicates, whether factual or typical or universal or ideal truths, it points to some kind of truth. Even if a literary text implies that there is no fixed truth to be discovered, that is the paradoxical truth of the text.

The two views mentioned earlier, that literature is expression and that literature is mimesis, both implicitly rely on the idea of a truth being communicated. If literature is expression, the question is: expression of what? The answer is: expression of the thoughts and feelings of the author. So it may be a subjective truth, but still there is that "something" behind the words, corresponding to what the words communicate. And if literature is mimesis, there is that mysterious "something" again behind the words, which the language of literature strives to "imitate". Both these views of literature, literature as expression and literature as mimesis, imply that the language of the text corresponds in some way to what happens to the author and what happens in society.

\subsection{Beauty}

In the Classical and Medieval philosophical tradition, beauty, with truth and goodness, was regarded as a transcendental "Property of Being"; as a transcendental and universal quality of existence. Many different views on and definitions of beauty were given, but essential in the concept was the idea of organic unity and inner harmony. In this tradition, beauty was not limited to the 
arts; it was regarded as an essential quality of the whole creation and the Creator.

In the 18th century, however, A.C. Baumgarten distinguished between natural beauty and the created beauty of the arts. He gave a new name, "Aesthetics", to the study of beauty in the arts; and this term came to be generally accepted.

In some ways it was useful to distinguish between natural beauty in the world and the aesthetic element in the arts. In the outside world, something ugly can hardly be beautiful; in the work of art, however, the ugly may be an essential part of the whole. The ugly in art often adds a necessary element of contrast, it forms an essential part of the diversity of the whole. The aesthetic element in art is created by transforming the beauty and the ugliness of the world into an aesthetic unity.

Many different definitions of the aesthetic have been given, but there are common elements in most opinions. M.C. Beardsley (1985/6:527ff), in his seminal work titled Aesthetics, mentions aspects of the aesthetic experience "on which ... nearly everyone will agree". They are the following:

* "An aesthetic experience is one in which attention is firmly fixed upon heterogeneous but interrelated components."

* "It is an experience of some intensity."

* "It is an experience which hangs together, which is coherent" - it is characterised by unity.

* "It is an experience that is unusually complete in itself" - it is characterised by balance and equilibrium.

* Aesthetic objects are "make-belief"; they do not raise the question of reality; they "call forth from us the kind of admiring contemplation, without any commitment to practical action, that is characteristic of aesthetic experience".

It is not difficult to discover some links between these commonly held views on the aesthetic experience and the views of the Formalist critics on the nature and value of the literary work - the connection between "heterogeneous but interrelated components", coherence, unity, equilibrium mentioned above, and, on the other hand, the focus of Formalists like the "New Critics" on the amount and diversity of material integrated to form an aesthetic pattern or structure.

The important point in the argument is that the Formalists gave a central place to aesthetics and the aesthetic element in literature, and that their focus on aesthetics is linked to a very old philosophical tradition going back to Plato, who regarded beauty as one of the transcendental values. 
Although it makes some sense to distinguish between "beauty" and "aesthetics", a strong case could be made for linking the two concepts once more to each other and to the transcendental values of old. The separation of aesthetics from beauty, and also from ethics and truth, has led to a lack of moral and spiritual meaning in the contemplation of the arts. We should perhaps once more go to the Classical and Medieval roots of Western civilisation.

\subsection{Goodness}

The supposition that literature is an art of persuasion, is linked to the third transcendental value to be discussed, namely goodness. "Goodness", in all its different definitions, implies its contrast of "evil"; "goodness" is something one should adhere to; and evil something which should be avoided and opposed. If the implied author in literature is involved in the problems of the world, exposing its wrongs and attempting to change it for the better, persuading, influencing and transforming the readers in the process - then this activity is clearly linked to the value of goodness.

So we may conclude that traces of the transcendental and absolute values of truth, beauty and goodness permeate various views of literary theorists on the nature and value of literature.

\section{4. "Drought"}

"Drought" ("Droogte") by Jan Rabie is one of the short stories in Rabie's Een en twintig ("Twenty-one"), published in 1956 - a book that was to herald the movement of the "Sestigers" (those of the sixties) in Afrikaans prose. The title indicates that there are 21 stories in the book; it also suggests the author's coming of age. The book was published after a lengthy stay of the author in Paris.

The story "Drought" is about a white man and a black man building a house together; the white man remains inside the house, while the black man has to do the hard work and endure the heat outside. The house is built without windows and doors, so that ultimately the white man is locked up inside, and the black man is left outside, lonely and anxious.

I want to briefly analyse the concepts of beauty, truth and goodness, as expressed and implied in this story. In my analysis I cannot claim to find the objective existence of truth, beauty and goodness in the story; these values are found in my subjective involvement with the text; but I hope that there is something intersubjective in my involvement, and that my discoveries will, at least partly, be shared by the readers of this article; and that together we might discover and create meaning and truth in our involvement with the text and with one another. 


\subsection{Aesthetic structure}

In the first paragraph much of the essence of the whole story is given; it links up closely with what is to follow. The dust forms "pillars"; a strange way of describing it, immediately attracting the attention of the reader. Pillars are constructions to support a building; figuratively, the pillars of society are supposed to support the fabric of society. But these pillars are "whirling", they "walk" - the constructions of support are moving, and the whole building must therefore be expected to fall in. The earth is like a "floor" - something artificial and manmade, linking up with the image of the pillars. The implication is that the earth has been deformed by human beings into something strange and unstable something about to be destroyed.

"The landscape is that of drought." The drought, which is indicated in the title and also clearly suggested in the description, is mentioned explicitly unnecessarily, as Brink maintains (Brink, 1973:27). The important point for the argument here is that the emphasis on drought shows its thematic importance. The drought refers to more than a lack of rain; we find a spiritual drought due to the bad relationship between man and man. As a matter of fact, the symbolic meaning of the drought is explicitly stated in the opening paragraph, in the phrase "thirsty for green love". The drought of the story is primarily a spiritual drought caused by a lack of love.

Thus the first paragraph of the story, apparently merely describing the setting of the events, has a close link with what follows. Characters, events and the milieu are intertwined; together they express the central theme of the story: the catastrophe following a lack of love.

In the dialogue between the white and the black man a pattern emerges, a pattern of differences and conflict. The white man and the black man look at the past and the present in sharply contrasting ways. Behind the white man's presentation of reality lies the attempt to subject the black man; and the latter resists the attempt.

But slowly another pattern emerges: that of the successful subjection of the black man by the white man. When the black man expresses a reality painful to the white man ("You come to teach me that God is white. That I should build a house for the white man"), the white man has no other defence than to shout at the black man in a derogatory manner. The surprising effect of his shouting is that it actually has the desired effect - the black man mutters, "Yes, baas", and with that confirms his subjugation, with the "yes" as well as with the "baas". The pattern of the past is repeated, and will be repeated in the black man's helpnessness at the end of the story. 
This brief analysis suggests an underlying unity within the diversity of elements in "Drought". The contrasting characters, the changing situations, are all linked to the theme of a disastrous relationship of subjugation. Here we have the kind of aesthetic structure, the unity within a diversity of elements, which was appreciated by the "New Critics".

\subsection{Truth}

Together with the aesthetic element to be discovered in "Drought", we also find an element of truth, the second value to be examined. It is not the factual truth found in a law report, but rather a typical truth portraying aspects of the South African society of the fifties: a typical relationship between a white and a black man in a typical South African country setting. The story refers to the "outside world".

It is important to consider that the things of the outside world can never be referred to in a neutral way; every statement is accompanied by an attitude or rather a combination of attitudes. Fowler $(1977: 76,75)$ puts it as follows: "Language is a powerfully committing medium to work in. It does not allow us to 'say something' without conveying an attitude to that something." This also applies to literature: "Within every tale there speaks a detectable "teller": no novel is neutral, objective."

The concepts of "white man", "black man" and "the country" (platteland) have been filled with powerful ideological attitudes in traditional Afrikaner society before the fifties, also expressed in Afrikaans literature. In Afrikaans prose before the fifties, "white man" had a predominantly positive connotation, and "black man" a predominantly negative one. The black man was often depicted as stupid; the white man, in contrast, is the one who knows better, he is the parent or guardian of the black man. The black man is also seen as lazy, while the white man is hard-working. The black man is bloodthirsty and revengeful; the white man, on the other hand, is civilised, the one upholding Christian values (cf. Van der Merwe, 1994:35-44).

Furthermore, Afrikaans prose before the fifties typically places the whites in the centre of the story - the main characters are mostly whites, and black people are mostly absent or minor characters. Also, the whole perspective is usually that of the whites, appreciating what is their own and deprecating what belongs to the other.

To a large extent, Rabie turns tradition on its head. In "Drought", the black man joins the centre of the stage with the white man; and the black man is more truthful and also works harder than the white man. 
In the portrayal of the country, Rabie also turns against convention. Traditionally, the farm and the country are depicted positively in Afrikaans fiction. Traditional Afrikaner values could be maintained in the country whereas the city posed a threat to morality. The idyllic country is a dominant feature of traditional Afrikaans prose; so too, the moral danger of the city. Within this framework, drought is seen as a real threat to the farmer, because it might force him to leave the farm for economic reasons, and lead a life of poverty and decadence in the city.

The milieu in "Drought" is possibly a farm; in any case the story is set in the country. Here, nothing of the idyllic country can be found; it is an environment of stupidity, exploitation and selfdestruction. The real danger is not situated in the city, but in the attitudes inside the characters. The actual threat is not a physical drought, but a spiritual one.

Discussing the "truths" in Jan Rabie's "Drought", its reference to the outside world, two important points have emerged:

* The "truths" expressed by the implied author, the implied views on the white and the black man and the country, do not exist in a vacuum. They are reactions to beliefs dominant at a specific time and in a specific place, beliefs regarded as falsehoods by the implied author. The author's truths form part of a dialogue with society and tradition.

* Truth and goodness can hardly be separated, because the truths of the story are permeated by moral attitudes. The falsehoods of the white man are shown to be morally wrong; they are motivated by the desire to subject and the refusal to show consideration to his fellow-man.

\subsection{Goodness}

The latter point brings us to the third transcendental value, that of goodness, and the ways in which it is embodied in the story. I have already indicated that the moral attitudes of the implied author permeate the whole story. Let me briefly indicate three ways by which these moral attitudes are conveyed:

\subsubsection{The transgression of implied moral norms}

\subsubsection{The implied norms of truth and logic}

The white man is the guilty one in this respect. He talks "dreamily" about his past, clearly not taking reality into account, but rather expressing his wishes, and twisting history in the process ("on the land they built their wagons and covered them with the sails of their ships") 
The white man projects his negative feelings against the blacks onto the land in which they live, calling it "barbaric". He is condescending towards the black people, offering to "teach you blacks how to live in peace with us ... even if your skins will always be black ...". In his view, only the blacks must be taught; he does not consider the possibility that his people need some teaching - while Rabie's story clearly indicates that the whites are the ones badly in need of change. Furthermore, the white man takes himself as ultimate criterion of value, and presumes that a black skin is a sign of inferiority.

His self-centredness determines the nature of his theology: "Long ago my God cursed you with darkness". The white man has made God "his" God, using God for his own ends and conforming God to his own twisted mind; using "his" God to curse the black man. He links the blackness of the black man's skin to darkness and all its negative associations. Perhaps, in his mind, it is anxiety which subconsciously leads him to connect the two.

His lack of logic is blatantly shown in his answer to the black man's question about the lack of windows and doors in the house: "Long ago in another country my forefathers built walls to keep out the sea. Thick, watertight walls. That's why my house, too, has no windows and no doors" (my italics).

The white man is using the wrong data, those of the past in a vastly different situation, for the solutions of the problems of the present. His words refer to the dykes built in the Netherlands, where he came from, to keep the sea out; in this specific milieu, however, there is no sea. The only "sea" (threat) for the white man is the black man. To use the "literal" walls of the past to keep out a "figurative" sea is clearly ridiculous. The foolishness of the white man (and of the black man, as depicted towards the end of the story) confirms the view of Jan Spies (1982:455) that Rabie's story is based on a folk-tale about fools.

\subsubsection{The norms of fairness and righteousness}

The norms of faimess and righteousness cannot be totally separated from the norms of truth and logic, since the narcissistic attitude of the white man leads him to transgress both the norms of truth and of fairness.

The white man's total egoism is quite obvious. He remains in the shade, while the black man has to do the hard work in the blistering sun. He is unable to listen to the black man as a person in his own right; he can only command and shout at the black man. When the black man confronts him with an uncomfortable reality, the white man reacts by shouting and commanding the black man to keep quiet, instead of listening to what he is saying. 
Whereas the white man thinks of himself only, the black man perhaps thinks too little of himself. When the white man treats him in an unreasonable and autocratic way, the black man reacts submissively. That is why the black man cannot grow into an independent person, and feels alone and anxious when he is left without the white man in the end.

\subsubsection{Descriptions and symbols}

The symbolic drought is of prime importance in this story, suggesting that the present situation is highly undesirable. The drought and the heat are mentioned repeatedly in the story, and the title also accentuates the importance of this motif. The choice of words emphasizes the unbearableness of the drought and heat: "The sun glares down with its terrible eye." In contrast to the drought, the ideal of rain is implied.

The drought in the story, as mentioned, is a spiritual drought. The terribleness of oppression is revealed symbolically by the drought, and the desirability of justice and compassion by the implied ideal of rain. There is strong irony in the white man's expressed longing for rain, whereas, symbolically speaking, his attitudes prevent the rain from falling.

Viljoen (1993:31) suggests another facet of the symbolism in the story. He discusses the repetition of the contrast between horizontal and vertical lines, and points out that the horizontal lines are much more powerful than the vertical ones. $\mathrm{He}$ interprets this as a sign that the "heaven above" provides no way of escape. "Waar landskapsbeskrywing in Afrikaans gewoonlik met 'n indeks van 'vertikaal' eindig, dit wil sê 'n opkyk na bo, na God, soos in Bart Nel, word hierdie opkyk nadruklik vervang deur 'n rondom-kyk sonder uitsig" ("Whereas the descriptions of landscape in Afrikaans usually end with a 'vertical' index, that is a looking upwards, towards God, as in Barl Nel, this looking upwards is emphatically replaced by a looking around, without any prospect"). The absence of God is all the more reason for the two men to accept their "horizontal" responsibility and be kind towards each other.

\subsubsection{The conclusion of the events}

The catastrophic conclusion of events serves as a warning, indicating the inevitable result of the transgression of the implied norms. The story has a prophetic ring - justice will be done. In the end the narrator acts as a judge, as it were, and metes out the punishment according to the transgressions. The white man, who wanted to save his own life only, without taking others into consideration, ironically gets the death sentence. The life of the black man, whose transgressions were of a lesser nature, is saved; he is set free from the 
oppression of the white man, but does not acquire the freedom of an innerly independent individual.

So, from the above analysis, we may conclude that the story is based on the implied values of truth, beauty and goodness. In literature, as well as in literary theory, philosophy and theology, these values seem to be the foundation of all critical enquiry. It reminds one of the remark of L. Ruby (1968:44): "The history of philosophy may be regarded as the record of man's search for adequate analytical definitions of the key terms in human discourse, words such as 'truth', 'beauty' and 'goodness'."

\section{When the Absolute falls into the water ...}

There is an apparent contradiction in the theories of literature in the last few decades. On the one hand we find the realisation that the meaning and value of the literary text can never be fixed and constant, but change from reader to reader, from generation to generation and society to society - the meaning and value of each text is relative to its context. On the other hand, literary theory still seems to cling to age-old absolute values of beauty, truth and goodness. Is there a way to reconcile these apparently contradictory suppositions?

Bernard Bosanquet (quoted in Hoernlé, 1924:176) may provide the clue - "When the Absolute falls into water, it becomes a fish", he said. That is, the Absolute continually takes on different forms, determined by the context, yet still remains true to itself; always different, yet always the same.

Could it be that in every age, in every writer, and in each literary work, we always find new manifestations, new "incarnations" of the time-honoured values of beauty, truth and goodness? Always new attempts at formulating the unfathomable ideas? In every new situation goodness and truth seem to take on different forms; in each new search for goodness and truth the writer must find new structures to convey new messages. And yet, always changing, the values of beauty, truth and goodness remain true to themselves: truth is always that "something" behind the words; goodness always implies a moral obligation; and beauty always implies a pattern or structure.

\section{A dialogue of Love}

In all communication, including that of literature, the ideas are always communicated in the form of a dialogue; in all communicative situations we have specific senders and receivers of a message. That brings us to the last and most fundamental of ideas conveyed in literature: the idea of love or charity. 
Love is the essential prerequisite for any successful dialogue. J. Hillis Miller (1975:45) aptly formulated this point:

... The proper model for the relation of the critic to the work he studies is not that of scientist to physical objects, but that of one man to another in charity. I may love another person and know him as only love can know without in the least abnegating my own beliefs. Love wants the other person to be as he is, in all his recalcitrant particularity. As St Augustine puts it, the lover says to the loved one, 'Volo ut sis!' - 'I wish you to be.' If the critic approaches the poem with this kind of reverence for its integrity, it will respond to his questioning and take its part in that dialogue between reader and work which is the life of literary study.

What is love? Love is, like the other absolute ideas discussed, an unfathomable concept; but let us begin with generally accepted qualities of love: an opening up towards the other, seeing the other as a fellow human-being, noticing his / her potential and responding to his / her needs.

Perhaps the most meaningful utterance in "Drought" is the following: "thirsty for green love the vast and arid plain treks endlessly out to its horizon". Is this not the central message of the story: the importance of love; and the catastrophic results of the absence of love?

This is the basic problem with the white man of the story: that he does not respect the black man as his fellow-man, because in his self-centredness and feelings of racial superiority the white man has no room for love. With this realisation we have also come to the diagnosis of the illness of the South African society depicted in the story: a spiritual drought caused by lack of love. It is love alone that will break the drought.

The solution of the suggested problem in society might begin with a writer like Rabie who, seeing the lack of love, noticing what others failed to see, and, motivated by love, does something about it: he writes a story to take away the blinkers from the eyes of the readers, to reveal what everybody has been ignoring and denying. The solution might be taken further by a reader open to the message of the story, and also open to the challenging possibility of applying the message of the story to society; a reader whose openness to the text is transferred to society, to revive society with an openness to the other.

Behind the values of truth, beauty and goodness is the more fundamental value of love, embracing and transcending all the other values. Love, an openness to the other, is the precondition for discovering the truth about self and the other; love is the driving force behind all goodness; and also the harmonious co-existence of disparate elements, called beauty, is closely linked to the concept of love. 
Let me add a sixth inadequate definition of literature to the five already mentioned: Literature is a dialogue of love, in which aspects of beauty, truth and goodness are integrated.

Through love the absolute and the relative are linked. "Love" always implies a relationship and must therefore always be relative to those involved in the relation; but openness to the needs and potential of the other are constantly present in love. In every relationship between author and reader there is something new; every society to which the message of the text is applied, is unique; but always present is the reality of the ideal of love. Love makes abstract absolute values like truth and goodness concrete, connecting them to specific places and people. It is love which notices and expresses the needs of the self and the other, because love cares; it is love which permeates all the portrayals of brokenness and desire. In love we find the motivation and meaningfulness of all literary communication.

The concept of love has become shallow through superficial usage. The love I am speaking of, is linked to truth - it is clear-sighted, aware of complexities and ambiguities; it also has a place for the ironies of life. For without irony, love can easily become sentimental. The poet N.P. van Wyk Louw expressed this need to combine love and irony, as follows:

eintlik moet ons leer ironies lewe

én: binne ironie nog liefde hou.

["actually we should learn to live ironically

and: within the irony make room for love."]

When we realise the fundamental importance in literature of this expansive love, containing in itself the unfathomable depths of truth and goodness as well as of beauty, we may rediscover a mystic element in the writing and studying of literature. If what the apostle John said should be true, that God is love, then all literature points towards God. Perhaps we should once more consider the significant words of the Flemish poet Guido Gezelle, put in the mouths of little animals aptly called "schrijverkes" (little writers), because they continually move on the surface of the water, as if they were writing something. Gezelle (s.a.) lets them say:

Wij schrijven en schrijven en schriven nog eens den heiligen Name van God.

We're writing and writing and writing once more The holy Name of God. 


\section{References}

Beardsley, M.C. 1985(6). Aesthetics from Classical Greece to the present: A short history. Alabama : University of Alabama Press.

Brink, André P. 1973. Jan Rabie se 21. Kaapstad: Akademika.

Caws, P. 1966. The philosophy of science. Princeton, New Jersey : Van Nostrand Company Inc

Collins Concise English Dictionary

See

Guralnik (1978)

Guralnik, D.B. (ed.) 1978. Collins Concise English Dictionary. Glasgow : William Collins.

Fowler, R. 1977. Linguistics and the novel. London: Methuen

Gezelle, G. s.a. Dichrwerken. Amsterdam : L.J. Veen.

Hillis Miller, J. 1975. Literature and religion. In: Tennyson, G.B. \& Ericson, Edward E. Jr: Religion and modern literature: Essays in theory and criticism. Grand Rapids, Michigan : Eerdmans. p. 31-45.

Hoernlé, R.F.A. 1924. Idealism as a philosophical doctrime. London : Hodder \& Stoughton.

Phillips, R.P. 1957. The properties of being. In: Modern Thomistic philosophy. The Newman Press. p. 174-179.

Preminger, A. (ed.) 1990. Princelon encyclopedia of poetry and poetics. Princeton : Princeton University Press.

Rabie, Jan. 19633. Droogte. In: Een-en-twintig. Kaapstad : Human \& Rousseau.

Rabie, Jan. 1987. "Drought". In: Trump, Martin. Armed vision. Afrikaans wrilers in English. Johannesburg : Ad Donker p. 23-25.

Rahner, K. (ed.) 1970. Transcendentals. In: Sacramentum mundi. An encyclopedia of theology. London: Burns \& Dates. p. 285-287.

Ruby, L. 1968. The arl of making sense. London: Angus \& Robertson.

Spies, Jan. 1982. Jan S. Rabie. In: Nienaber, G.S., Antonissen, Rob \& Brink, André P. (reds.) Perspektief en profiel. Vyfde, hersiene uitgawe. Johannesburg : Perskor. p. 453-462

Van der Merwe, C.N. 1994. Breaking barriers. Stereotypes and the changing of values in Afrikaans fiction, 1875-1990. Amsterdam : Rodopi.

Viljoen, Hein. 1993. Jan Rabie se "Droogte": tekstuele masjien of ideologiese voetangel? Stilet, 5(1):23-36.

\section{Supplementary reading list}

Abrams, M.H. (ed.) 1957. Literature and belief. New York: Columbia University Press.

Bosanquet, B. 1956(8). A history of Aesthetics London: George Allen \& Unwin.

Glicksberg, C.I. 1960. Literature and religion: A study in confiict. Dallas : Southern Methodist University Press.

Goldmann, L. 1973. Der verborgene Gott. Neuwied : Luchterhand.

Hudson, W \& Van Reyen, W. (reds.) 1986. Modernen versus Pos/modernen. Utrecht : HES.

Krapicek, M.A. 1991. Metaphysics: An outline of the history of being. Translated by T.H. Sandok. New York : Peter Lang.

Kuhus, R. 1971. Literature and philosophy: Siructures of experience. London : Routledge \& Kegan Paul

Lerner, L. 1960. The truest poetry. London : Hamilton.

Lodge, D. 1988. The novel now: theories and practices. Novel: A forum on fiction. (Why the novel matters: A postmodern perplex.) Vol. 21(2\& 3):125-138

Mooij, J.J.A. 1987. De wereld der waarden. Amsterdam : Meulenhoff 
Nussbaum, M.C. 1990. Love's knowledge: essays on philosophy and literature. Oxford Oxford University Press.

Scott, W. (ed.) 1962. Five approaches of literary criticism. New York : Macmillan.

Spacks, P. 1988. The novel as ethical paradigm. A forum on fiction. (Why the novel matters: A postmodern perplex.) Vol. $21(2 \& 3) ; 181-187$.

Wimsatt, W.K. \& C. Brooks. 1957. The Neo-Platonic conclusion: Plotinus and some Medieval themes. In: Literary criticism: A short history. New York : Knopf. p. 112138.

\section{Appendix}

\section{Drought ${ }^{3}$}

\section{Jan Rabie (1951)}

Whirling pillars of dust walk the brown floor of the earth. Trembling, the roots of the withered grass await the rain; thirsty for green love the vast and arid plain treks endlessly out to its horizon. One straight ruler-laid railway track shoots from under the midday sun's glare towards where a night will be velvet-cool with stars. The landscape is that of drought. Tiny as two grains of sand, a white man and a black man build a wall. Four walls. Then a roof. A house.

The black man carries blocks of stone and the white man lays them in place. The white man stands inside the walls where there is some shade. He says: "You must work outside. You have a black skin, you can stand the sun better than I can.'

The black man laughs at his muscles glistening in the sun. A hundred years ago his ancestors reaped dark harvests with their assegais, and threshed out the fever of the black sun in their limbs with the Ngoma-dance. Now the black man laughs while he begins to frown.

'Why do you always talk of my black skin?' he asks.

'You are cursed,' the white man says. 'Long ago my God cursed you with darkness.'

'Your God is white,' the black man angrily replies. 'Your God lies! I love the sun and I fear the dark.'

3 Rabie's translation as published in Trump, Martin 1987. Armed vision. Afrikaans writers in English. Craighall : Donker. p. 23-25. 
The white man speaks dreamily on: 'Long ago my forefathers came across the sea. Far they came, in white ships tall as trees, and on the land they built their wagons and covered them with the sails of their ships. Far they travelled and spread their campfire ashes over this vast barbaric land. But now their children are tired, we want to build houses and teach you blacks how to live in peace with us. It is time, even if your skins will always be black ...'

Proudly the black man counters: 'And my ancestors dipped their assegais in the blood of your forefathers and saw that it was red as blood. Red as the blood of the impala that our young men run to catch between the two red suns of the hills!'

'It's time you forgot the damned past,' the white man sadly says.

'Come you must learn to work with me. We must build this house.'

'You come to teach me that God is white. That I should build a house for the white man.' The black man stands with folded arms.

'Kaffir!' the white man shouts, 'will you never understand anything at all! Do what I tell you!'

'Yes, baas,' the black man mutters.

The black man carries blocks of stone and the white man lays them in place. He makes the walls strong. The sun glares down with its terrible eye. Far, as the only tree in the parched land, a pillar of dust walks the trembling horizon.

'This damned heat!' the white man mutters, 'if only it would rain.'

Irritably he wipes the sweat from his forehead before he says: 'Your ancestors are dead. It's time you forgot them.'

Silently the black man looks at him with eyes that answer: Your ancestors, too, are dead. We are alone here.

Alone in the dry and empty plain the white man and the black man build a house. They do not speak to each other. They build the four walls and then the roof. The black man works outside in the sun and the white man inside in the shade. Now the black man can only see the white man's head. They lay the roof.

'Baas,' the black man asks at last, 'why has your house no windows and no doors?'

The white man has become very sad. 'That, too, you cannot understand,' he says. 'Long ago in another country my forefathers built walls to keep out the sea. 
Thick, watertight walls. That's why my house, too, has no windows and no doors.'

'But there's no big water here!' the black man exclaims, 'the sand is dry as a skull!'

You're the sea, the white man thinks, but is too sad to explain.

They lay the roof. They nail the last plank, the last corrugated iron sheet, the black man outside and the white man inside. Then the black man can see the white man no more.

'Baas!' he calls, but hears no answer.

The Inkos' cannot get out, he thinks with fright, he cannot see the sky or know when it is day or night. The Inkos' will die inside his house!

The black man hammers with his fists on the house and calls: 'But Baas, no big water will ever come here! Here it will never rain for forty days and forty nights as the Book of your white God says!'

He hears no answer and he shouts:

'Come out, Baas!'

He hears no answer.

With his fists still raised as if to knock again, the black man raises his eyes bewilderedly to the sky empty of a single cloud, and stares around him at the horizon where red hot pillars of dust dance the fearful Ngoma of the drought.

Alone and afraid, the black man stammers:

'Come out, Baas ... Come out to me ...'

Translated by the author 